\title{
NEWSROOM DIVIDES: ONLINE NEWS PRODUCTION, GENDER, AND ORGANIZATION AT DN.SE
}

\author{
AUTHOR: HULTEN, Gunilla \\ Assistant Professor - Stockholm University - Sweden \\ gunilla.hulten@ims.su.se
}

\begin{abstract}
The crisis of the news media industry has changed the conditions of news reporting, placed pressure on the journalism profession, and affected its professional identity.

In the last few years, online newsrooms have undergone significant changes in their organization and their practices of production. This article presents a case study of the relationships between gender, news production, professional routines, working conditions, and attitudes toward gender equality in the online newsroom of DN.se, the news website of Dagens Nyheter, Sweden's largest morning newspaper.
\end{abstract}

Like many newspapers worldwide, Dagens Nyheter faces difficulties in maintaining its readership, and has recently implemented major reorganizations, including staff cuts and budget reductions in the online newsroom. These changes also have had an impact on the daily work practices of reporters, including increased workloads and conflicting professional ideals.
The journalists at DN.se generally express a broad awareness of gender parity. However, women's voices, experiences, and expertise continue to be significantly underrepresented in the news content. The DN.se online news replicates the patterns of gender portrayal and representation observed in traditional print news media in Sweden and internationally.

It is argued that intensified market pressure and increased competition for readers, combined with the lack of goaloriented policies, are all promoting a type of journalism which is potentially threatening to gender parity in online newsrooms.

\section{Key words}

Gender, online newspapers, news production, gender representation, equality.

\section{Introduction}

Swedish and international research has provided comprehensive knowledge of gender in traditional news media like newspapers, radio, and television, including studies of women's representation in news content and story types, the use of women as sources, and their subordinate positions in mainstream newsrooms (see e.g. Bruin \& Ross 2005, Edström 2006; Gallagher 1995, Kleberg 2006; Löfgren Nilsson 2004; Tuchman 1981; van Zoonen 1998). There is equally substantial research covering different aspects of online journalism, such as interactivity, convergence, business models, working conditions, sources, technology, challenges, and history (see e. g. Anderson 2013; Domingo \&
Paterson 2011; Hinderson 2013; Jones \& Salter 2012; McChesney 2013).

However, little has been written on the gender aspects of online news production. The contributions of de Cabo et al. (2014), Yun et al. (2007), and of Burke and Mazzarella (2008) do give valuable insights into the representation of women in Spanish online news content, of the portrayal of women in online news magazines in the United States, United Kingdom, Korea, and Mexico, and of the gendering of the lead news stories appearing in the online versions of the television networks CNN and FoxNews as well as the national newspaper New York Times. De Cabo et al. contended that the Spanish online news- 
papers continued to perpetuate the underrepresentation, stereotyping, and discrimination of women in web news, thereby reinforcing gender inequality. Yun et al. argued that online media offers a potential for more diverse content with equal coverage that traditional print and broadcast media typically lack (Yun et al. 2007). Burke and Mazzarella (2008) agree that the internet has the potential of creating a genuine change in news coverage and journalistic practice, but found that this potential has not been achieved, and that the differences between mainstream internet news and its print counterparts were merely cosmetic.

Recent changes within the media industry have undoubtedly had profound implications on the journalistic professionalism (e.g. Deuze 2005; Fenton 2010; Nikunen 2013). Intensified market pressure, a concentration on cost reductions, and the expansion of multimedia platforms challenge the conditions of the journalistic profession and equally call for a need to examine the professional values and identities in online newsrooms and on how these are connected to gender. As media scholar Milly Buonanno points out, there is a growing demand for research on "the increasing complexity of the relationship between gender and media in times when old and new intersect, converge and merge" (2014: 16).

Currently the global news industry is undergoing an acid test, and Sweden is no exception. In this article I present a case study of the news representation of women and men, and specifically the professional routines, working conditions, and ideals of journalism in the online newsroom DN.se, the news website of Dagens Nyheter (DN), Sweden's largest morning newspaper. This newspaper faces difficulties in maintaining its readership and its advertising revenues, and has implemented major reorganizations, including staff and budget cuts, which included the online newsrooms. These changes also have had an impact on the daily work practices of the online reporters and editors in terms of workload, distribution of work, and newsrooms practices.

\section{Objectives}

This study draws on theories concerning news values, news production, newsroom organization, online journalism, and feminist media studies. Using a multimodal approach, the aim here is to identify how or whether gender plays a role in the processes of producing, selecting, and presenting news, and to gather a base to discuss the professional routines, working conditions, organizational policies, and professional ideals with a specifically gendered perspective in mind. Central research questions are:

- How are women and men represented in the online news content of DN.se?

- What characterizes the professional practices and working conditions of reporters and editors at DN.se?

- What are the professional ideals and values of the reporters and editors at DN.se?

- How does the editorial staff express attitudes toward gender equality?
The discussion of the article is structured around three overarching divides: the representation of women and men in the online news content and staffing, the division of employment status between female and male journalists, and the tension between the journalists' professional ideals and practices.

I begin with introducing the methods and the different sets of data used in the study. Subsequently I present a research review of news values, gender and news journalism, and of online newswork. I then present the organization and composition of the DN.se newsroom. The following overview of the quantitative analysis of the news content in DN.se is coupled with the results of interviews with the editorial staff and the results of observations from the newsroom. From there I move on to the ideals and practices of the reporters and editors. In the conclusions I discuss the themes in light of the patterns of the news content, the working conditions, and the attitudes among the editorial staff, bringing into focus the specific features of online newswork and 
how these are influenced or not by gender. I argue that the intensified market pressure, the concentration on cost reductions, and the usage of web met- rics all create a fast track journalism which places gender parity in online newsrooms on the backburner, and earlier accomplishments at risk.

\section{Methods and data}

The methods used are a combination of quantitative content analysis of online news items, observations of the newswork, and individual semistructured interviews with the reporters and editors of DN.se.

The online news items for the quantitative overview were collected from a two-week period, from 28 March to 10 April 2011. The first ten so called "news packages" on "the platform", that is the column of the start page where the most important and latest news are presented and updated, were saved at noon every day. A single news package can include headline, lead, photo(s), and links to previously published news on the same topic. In addition, all news published between 11 a.m. and 1 p.m. on the subsites labelled The Front-page, Stockholm, Economy, Sports, The World, Culture and Entertainment were collected. The material comprised a total of 460 news items. The content was coded for 18 variables by three coders who received thorough training and instructions prior to the coding. The observations and interviews were conducted by the author during a two-week period from 6 April to 19 April, 2011.

All 24 reporters and editors working in the online newsroom were individually interviewed. The interviews were done at the respondents' workplaces, were semi-structured, between 30 and 45 minutes long, and were digitally recorded and transcribed in their entirety. The method used for constructing the questionnaire and for analysing the data has largely been inspired by McCracken (1988). The interviews focused on the following overarching themes: news production, working conditions, editorial organization, gender equality, responsibilities, and ideals. The written results analysis process aimed at discer-ning and organizing the emerging patterns and themes in the respondents' answers (McCracken, 1988).

The observations concentrated on the daily routines of news production, news values, the use of sources, editorial planning and decision-making, and organizational conditions. I was present in the newsroom during all workdays, except for Saturdays and Sundays. My observations were followed by careful and continuous note taking. I observed the reporters and editors, and how they interacted, planned, and executed their assignments. I also attended editorial meetings and continuously talked with the reporters and editors about what they were doing, how, and why.

\section{News values, news production, and gender}

The concept of news values comprises both the editorial evaluations of what is reportable and the factors that govern the selection. It includes the journalistic approaches of constructing and presenting events that are perceived as newsworthy, and the legitimatizing of these choices. Journalistic news values include timeliness, relevance, and identification. The media sociologist Gaye Tuchman uses the metaphor the news net to describe the process of how events are converted into news, and of how the unexpected is made into the routine. The mesh of the news net is designed to catch big fish and thus arrange social reality according to specific lines (Tuchman 2003). In addition, a number of organizational factors contribute to the selection process so it can be carried out on a consistent and regular basis. Johan Galtung and Marie Holmboe Ruge present in an often cited article the 12 criteria needed in order for an event to be selected as news. Among those are: it must have occurred recently, it should be unambiguous, it should concern social elites or elite nations, it should refer to persons, and it should refer to something negative (1981). Since its development, 
this taxonomy has been criticized and further refined by several scholars (cf. O'Neill \& Harcup 2009).

Sigurd Allern distinguishes between traditional news criteria and a set of what he describes as "commercial news criteria“" (Allern 2002: 145). He contends that traditional news values don't suffice to explain the selection process. Instead, market considerations are crucial regarding what news items are prioritized and produced. He identifies three factors that are of decisive importance in this process. One concerns the geographical area of coverage and type of audience. Events that take place outside the newspaper's area of interest may be considered non-events. The second factor is competition, and the third general factor is the budget allotted to news departments, which is an expression of the company's commercial/ financial objectives (Allern 2002).

Most studies on news values and what is considered newsworthy refer to news appearing in newspapers, on the radio, and on television. It has been argued that web journalism basically adheres to traditional news values (cf. Hedman 2006). However, Chris Anderson calls attention to how the transitions in the news industry impact on the news criteria. He argues that the monitoring of reader behaviour and traffic on the news websites challenges longstanding journalistic conventions about "what counts" as news (Anderson 2009).

According to Gaye Tuchman, the new news media represent the apotheosis of commodification. With this she means: "the subordination of public and private realms to the logic of capitalism. In other words, things (eg, friendship, women) are valued for their commercial value" (Tuchman 2007: 11). In her view, commodification is taken to be a law of nature. Online news items are commodities valued by the number of clicks they generate in relation to the cost of production. Maximizing traffic is a vital element when trying to explain what drives editorial decision making (cf. Jones \& Salter 2012).

\subsection{Gender in the newsroom}

There are approximately 26,000 employed journalists in Sweden. Until the 1980s, newspaper journalism was a clearly male dominated field. Today more than half of all journalists are women (Statistics Sweden 2013). In addition, an increasing number of women hold leading positions in the news industry. In 2014, the share of female news editors in Sweden was around 40 per cent (Edström \& Mølster 2014: 47). However, this parity in numbers doesn't correspond to equality in terms of news content. In many fields, news coverage is still characterized by a male dominance. Even though the gender-typing of areas of coverage has subsided during the past 20 years, a gender based division of labour is still apparent in Swedish newsrooms (Djerf-Pierre 2007; Edström 2012).

Gaye Tuchman (1981) influentially employed the term "symbolic annihilation" to describe the media representations of women, which were characterized by condemnation, trivialization, or absence. Since then, several and more recent studies have pointed in the same direction (e.g. Edström 2006; Eide 1993; Ross \& Carter 2011). A number of investigations have documented a consistent male dominance among media sources. A survey of women's and men's presence within Swedish news journalism carried out in 2010 showed that 30 per cent of those appearing in images and articles were women. This pattern of a 70 per cent male dominance in the news output has been replicated in a variety of studies since the mid 90s (Edström, Jacobson \& Lindsten 2010). The latest Swedish study, carried out in 2015, which examines the websites of the twelve newspapers with the widest reach, shows exactly the same proportions between male and female subjects in the content (Rättviseförmedlingen 2015). These outcomes concur with international results in terms of women's and men's representation in news coverage. Media scholar Karen Ross found in her exploration of three local British newspapers that 67 per cent of the sources were male, and 33 per cent female. Women were three times more likely to appear as members of the public as were men, while men were twice as likely as women to speak as representatives of business (Ross 2011). The largest and most recent international study to date, the Global Media Monitoring Project (GMMP), documented news media coverage of women on a particular day (10 November 2009) in 108 count- 
ries. The study showed that women's presence in the news was 24 per cent. In contrast, more than three out of four people in the news were male. The percentage of female subjects in news was less pronounced in topics of high priority on the news agenda, such as politics and economics (WACC 2010).

Much of newsroom sociology research suggests that gender plays a minor role in how and what news reporters cover (Steiner 2009, 2012, 2014). Stephanie Craft and Wayne Wanta (2004) found that women's news judgments resemble those of men. Female and male reporters tended to cover a similar agenda of issues only when they worked for newspapers with a high percentage of women in managerial positions. Male-dominated newsrooms, meanwhile, tended to have male reporters cover political beats. Female reporters at these newspapers, conversely, were more likely to cover business and education beats. Gender parity in the newsroom does not automatically lead to parity in news content. As Gaye Tuchman contended "it is difficult for women employees to resist ideas and attitudes associated with success in their profession, even if those ideas disparage women, for sexism, like racism, is best understood as an institutional, not a personal, phenomenon" (Tuchman 1979).

\subsection{Online news production}

Worldwide, the newspaper industry is under severe financial pressure, with declining readerships and advertising revenues. In the 1980 s, about 75 per cent of the Swedish population read a morning newspaper every day. The decline started around the turn of this century, and in 2014 the daily reach of morning newspapers was 54 per cent (Nordicom 2014). Newspaper publishers are currently revising existing business models, including an ongoing move from print to digital and a search for new revenue streams. The hopes that digital advertising and paid digital content would replace the declining print revenues remain to be fulfilled. At the turn of the century, convergence was the buzzword in the news media industry (see e.g. Deuze 2004; Fagerjord \& Storsul 2007; Singer 2004). Formerly sepa- rate newsrooms and other parts of the media company would ultimately converge and cooperate. Multiplatform integration was predicted, and the metaphor "one kitchen, several restaurants" came into use to describe the ideal newsroom multimedia model. Multimedia production was the leading element in the forecasts of how news media would be transformed, which also required multi-tasking journalists. The assumed end-point was the fully integrated presentation of news stories through a variety of media, such as a website, print, radio, and television. This was also presented as the solution to how newspaper publishers and media houses should tackle their challenges. Critique has been raised towards the concept of convergence, but as an ideal it has nevertheless remained strong.

The shift to online journalism that started in the 1990s has had a rapid effect on news culture (Jones \& Salter 2012). Journalism scholar Sue Robinson argues that in providing raw material, hyperlinks, multimedia, and interactive possibilities with readers, online newspapers are creating a new form of journalism involving changes of journalistic missions, routines, and societal relationships (Robinson 2007).

Within the present transition and crisis of news media, the strategies among the media companies have diverged. The structural changes are complex, and involve diverse developments. DN.se is one example of a newsroom that has moved away from the ideal of integration and towards a specialized online journalism distinctly separated from the print newswork. This has implications on gender related issues in the newsroom of DN.se, including the daily work practices and status of the editorial staff, as will be discussed below.

\subsection{The online newsroom of DN.se}

Dagens Nyheter is the leading Swedish morning paper. It is an elite paper, in publication since 1864 , and is strongly branded with an ethos of quality. It is owned by Bonnier, Sweden's major media company. In 2012 Bonnier published six daily papers, which represented nearly one-fourth of the total daily press circulation (Facht 
2012: 30). During the period of 2001 to 2010, the circulation of Dagens Nyheter dropped nearly 20 per cent, from 360,500 to 292,300 daily copies (TNSSifo 2010). ${ }^{\mathrm{i}}$ At the same time advertising revenues of printed newspapers had been declining. The metropolitan morning papers have taken the hardest hit (Presstödsnämnden 2012: 13). In 2012 Dagens Nyheter's advertising sales fell 11 per cent (AB Dagens Nyheter 2012: 2). This decrease continued in 2013 and 2014 (AB Dagens Nyheter 2014: 18).

Sweden's first newspaper website was launched by Aftonbladet in 1994, which is now the most popular news site. It was soon followed by Svenska Dagbladet and Göteborgs-Posten, both among the largest Swedish morning papers (Hinderson 2013). The newspapers almost invariably chose to make their online publications available to users, free of charge (Presstödsnämnden 2012: 4). This policy has changed, however, and today several Swedish newspapers have implemented paywalls, which require readers to pay in order to access online content.

Dagens Nyheter started its first web edition in 1996, and since then has undergone several changes. It started out as dn.net and was later renamed DN.se, using the well-known logotype of the print edition on the news site. Most newspapers in Sweden have web sites, but have chosen different paths in their organization of the online news work. Some have opted for integrated print and online newsrooms, others have separated them.

At the time of the investigation the newsroom of DN.se was situated at the far end of one floor that housed the entire editorial of Dagens Nyheter. The staff of DN.se worked at desks placed in six rows with four desks in each row. The reporters and editors had individual desks, each equipped with two computer screens. The online newsroom was spatially and organizationally separated from the print newsroom. It consisted of web-only editors and reporters who were detached from their colleagues who were working with the print edition.

DN.se has significantly more male than female readers, 58 per cent of the readers are men and 42 per cent women. The highest readership is among those between 25 and 34 years; one fourth of the readers are found in this age group. Welleducated, high-income earners and decision makers are overrepresented among the readers in relation to the Swedish population as a whole (Dagens Nyheter 2011a). At the time of the study, DN.se had 1.47 million unique visitors per week (Sveriges Annonsörer, 2011).

As mentioned above, every other journalist in Sweden is female. The newsroom of DN.se, however, was male dominated. The online newsroom staff had 24 members, out of whom 15 were men and 9 were women. The oldest was 60 years and the youngest 25 years. The average age of all reporters and editors was 40 years, with a slightly higher average age among the men, 42 years, and a somewhat lower average age among the women, 36 years. This corresponds fairly well to the average age of Swedish journalists (Djerf-Pierre 2012). The professional experience varied between 6 months and more than 30 years. More than half of the women were employed by the recruitment agency Marieberg Media (see Table 1) on shortterm contracts, while the male reporters, with the exception of two, had permanent positions and were employed by Dagens Nyheter. There were differences in wages and in benefits between these groups. Those employed by the recruitment agency had considerably lower wages than those employed by Dagens Nyheter. The latter also received benefits, such as subsidized meals in the canteen, which those who were employed by Marieberg Media were not entitled to.

Table 1: Employment status at DN.se.

\begin{tabular}{|c|c|c|c|}
\hline Employees & Dagens Nyheter & Marieberg Media & Total \\
\hline All & 17 & 7 & 24 \\
\hline Female & 4 & 5 & 9 \\
\hline Male & 13 & 2 & 15 \\
\hline
\end{tabular}

Source: Own elaboration

As stated above, the online newsroom was a separate organization within Dagens Nyheter. It was managed by an editor-in-chief and three news editors. The workday started at $5.30 \mathrm{a} . \mathrm{m}$. and ended at 1.00 
a.m. Most of the reporters and editors worked in shifts, making up one early morning team and one night team. The teams worked ten hours a day and every other weekend. The staff of DN.se exclusively published their items on the news website and not in the print edition, and vice versa. In 2010 a major reorganization of Dagens Nyheter was implemented. The change included general staff cuts and reductions in budgets. The online newsroom was reduced from 45 to 25 employees, and some of the print journalists that had been made redundant felt obliged to apply for vacant positions as web journalists. When this study was conducted, the online newsroom was still shaken by the downsizing.

The cuts were a hard blow. My work has become more strenuous. /.../We had to take on a bunch of people from the newspaper that didn't fit in the new organization. In some cases, it was people who didn't have a clue about online news and would rather not be on DN.se. (R 1)

If they had the choice, some of the journalists would rather have had other work assignments. One editor expressed it in this way: "Basically it's good to change jobs, but you would prefer it to be voluntary" (R 9). In deciding who would go and who would stay, the rule of "last hired, first fired" prevailed. But this approach did not affect the journalists hired by the recruitment agency. In the process some of the more experienced journalists were made redundant, while less qualified ones were retained. This resulted in tensions within the newsroom, one journalist explained:

They let me stay and got rid of others. Of course it was weird, we all felt that. Many thought it was unfair that DN kept temporary workers and sacked permanently employed journalists. ( $R$ 2)

Many of the permanently employed journalists reacted against the differences in terms of employment between the two groups. One summarized:

Those hired by Marieberg have lower wages and benefits. I think they should be employed by Dagens $\mathrm{Ny}$ heter. It's really very unfair. We do the same job but they have much worse conditions. (R19)
And added one: "It's just crazy, because those from the recruitment agency are hard-working, talented journalists who work for slave wages" (R 1).

The reorganization also included an explicit division of Dagens Nyheter's online and offline content. In order to strengthen the position and brand of the printed newspaper and to provide subscribers with unique material, DN.se was restricted to publishing no more than 30 per cent of their printed articles on the website. In addition, printed in depth material and columns were not to be published online.

\subsection{The news content of DN.se}

The quantitative overview of the 460 news items published in DN.se during the investigated period shows that news about the economy, sports, culture/entertainment, foreign conflicts, and crime are prioritized on the news site. These findings largely concur with previous studies of print news (e.g. Hvitfelt 1985; O’Neill \& Harcup; Strömbäck 2008). The top five topics make up more than half of the number of news items (see Figure 1.) In addition, business and economic news together with foreign news are the most likely to be published on the opening page. The bottom five news topics are stories about children/youth, the military, science, home/family, and accidents. They constitute 7 per cent of the news content.

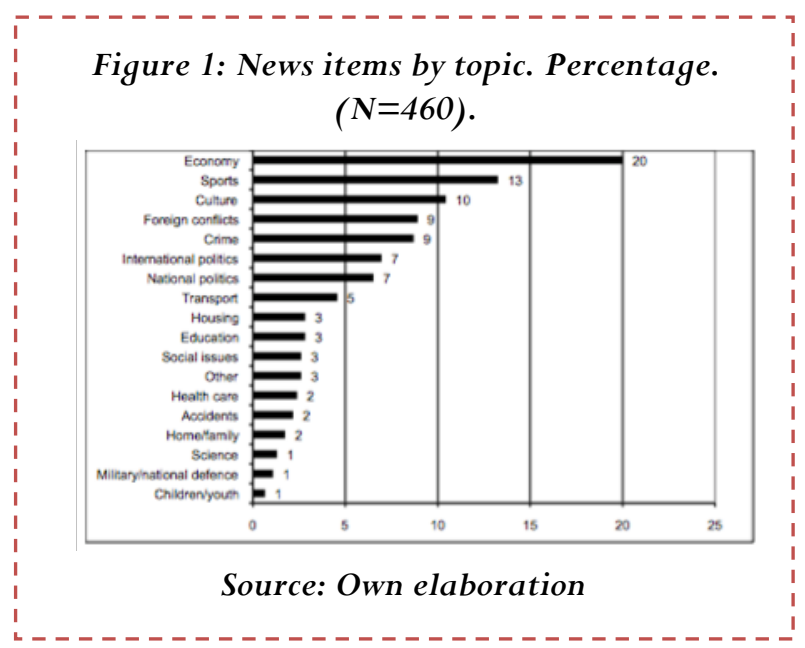

In the news published by DN.se, women are clearly underrepresented. As Figure 2 illustrates, a vast 
majority of the news items have a male main subject. The most obvious male dominance is to be found within the themes of sports, foreign conflicts, international issues, and crime. 30 per cent of all the main subjects are women, and 70 per cent are men.

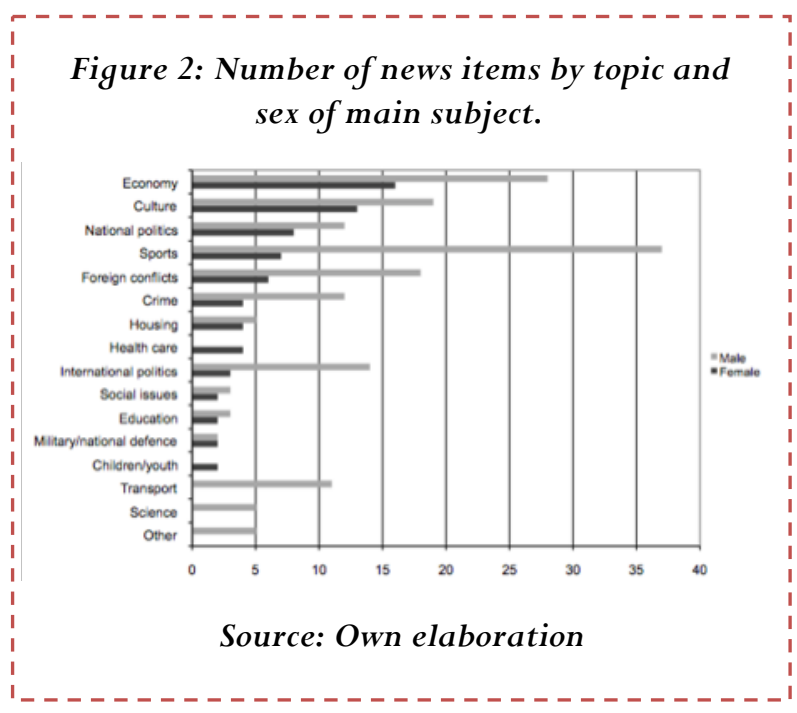

I also studied which elites were represented in DN.se. ${ }^{\text {ii }}$ Male elite sources outnumbered female elite sources by four to one. The political, economic, and cultural elites are the most frequently represented elites on DN.se. The political and cultural elites also have the highest levels of female representation.

Male sources are quoted nearly three times as often as female sources. Women are more likely to be quoted in stories about children, health care, housing, and culture. Men, however, are more likely to be quoted in stories about the economy, sports, international politics, and national politics. These findings largely concur with previous studies over the past decades. The proportion between men and women in the news content and the male biased use of sources in DN.se is consistent with a number of other studies on gender representation in the news media, which were conducted in various countries and at various times.

\subsection{Ideals and practices}

The DN.se web editors are constantly "deciding what's news" for the several thousands of daily visitors to the website. If a news item doesn't perform as well as expected, alterations are made, and the headline, lead, or image can be changed in order to enhance the traffic. The traffic of DN.se and of the competitor's news websites, Svenska Dagbladet, Ex-pressen, Aftonbladet, is displayed on large screens in the newsroom. Statistics on the of number of clicks per minute and the total site traffic of DN.se are con-tinuously updated. The screens also display which news items are currently the most clicked on. These statistics are showed on the reporters' and editors' computer screens. "It is the click feast which is valued", as one of the journalist expressed it (R 9). One continued:

You should not really care about the statistics, because as a journalist you should make an independent judgement. But it gives you mixed feelings to see that you are 100,000 clicks below what is expected. In that sense, it is stressful to know that we must be aiming to get more hits. (R 6)

In his ethnographic fieldwork of Philly.com, Chris Anderson observed patterns of news judgment different to the ones detected in print news. He links this shift primarily to the intense relationship between digital journalists, their audience, and web metrics (Anderson 2009). This is equally valid for journalism at DN.se.

According to its articulated core values, DN.se aims at being the most credible, reliable, continually up-dated, and leading news website. The website also has the goal to be surprising and inviting to its read-ers. DN.se aspires as well to offer in depth news that focuses on the unique possibilities of web production (Dagens Nyheter 2011b). However, several of the interviewees don't believe that the newsroom lives up to its goals. The main hampering factors that they mention are the time pressure, the workload, and the feeling of being stuck in the news flow. As one journalist put it:

\section{It's just that I have a list of stuff to do and it never ends. I would like to leave the office for five minutes and get some air. And it would be nice to have a coffee together now and then. (R3)}

Respondent \# 22 described the intensity of the work in a similar vein, and pointed out that this intensity is detrimental to the creative side of journalism.

Since we are such a lean organization, it is difficult to do anything more than what is in the news flow, which is a 
pity. /.../ We are so busy that we can't come up with ideas of our own to the same extent that you are able to when working for the print edition.

The primary job is to constantly keep track of the stream of news and select items for the site. Editors and reporters describe themselves as deskbound and tied to their computer screens. Press launches, for instance, are covered via online broadcasts from the office. Several others underline the intensity of the work due to the slimmed-down organization. Staff cuts have reduced the reporters' possibilities of working outside the building. "Before the downsiz-ing, it was not unusual for us to report from the out-side world. Now I can't remember when that last happened", said respondent \# 1.

According to some of the interviewees, the above jeopardizes the quality of the news work, and of journalism as a whole. Respondent \# 17 concluded:

Although the audience has moved from print to the web, the money hasn't followed. Assuming that print newspapers sooner or later will become marginalized, it is difficult to see how to finance quality journalism. I was more optimistic earlier than I am now. Online news has existed for 15 years or more, but it hasn't really taken off.

The web reporters have limited and few opportuni-ties to do in-depth and investigative stories. "That is the nature of the web", as some commented. When the interviewees were asked to describe how they viewed their role as journalists, a majority adhered to the journalistic ideals expressed by journalists as a whole in Sweden. About 80 per cent agreed that their most important key roles are to scrutinize those in power, and to explain com- plex events (Wiik 2007: 79). Respondent \# 14 summarized:

My basic and greatest professional joy is to investigate things, sort out how they fit together, and explain it. /... / Fast news is also fun, but it's not what I like the most. I would rather explain events and their contexts.

The journalists of DN.se generally believe that they are aware of the problem, and say that they strive for gender equality. However, DN.se has is no written diversity policy, and gender and other forms of di-versity have weak support at a managerial level. Initiatives to improve the current situation come from engaged individual editors or reporters. Most jour-nalists say that they do try to get female sources, but that they don't succeed in finding them. One journalist (R 2) stated: "You give up because we live in the real world. You cannot conjure up women if they don't exist." One pointed to organizational factors to explain what is prioritized: "The primary thing is to have the site updated and with the tight organization that we have now, it's a bonus to find time for any-thing else.” (R 6).

Despite the tiring and stressful work and the dissatisfaction with the working conditions that many ex-perienced, a majority expressed a positive attitude towards their colleagues and the working climate in the newsroom. Common words to describe this climate included "open atmosphere", "generous, "room for collaboration", "informal" and "non-hierarchical". Some also commented on the detached online news-rooms of DN.se in positive terms. The respondents were of the opinion that it gave them more freedom to shape their own newsroom culture.

\section{Concluding remarks}

The trend is unmistakable in Sweden and in most countries: fewer are reading print newspapers, as more turn to the internet for their news. The balance between online and print readership has changed substantially between 2003 and 2011. In 2011, online readers comprised 20 per cent of all newspaper readers. Eight years earlier, 3 per cent of morning newspaper readers viewed them online (Bergström \& Wadbring 2010). In 2014, the reach of online newspaper readership was 24 per cent
(Nordicom 2014). This is being driven by a substantial shift in how younger generations read newspapers. In view of the transformation of readership patterns, it is all the more important that online news sites live up to the generally accepted ideal of gender parity in the news room and in news content. It was one of the female editors who took the imitative in monitoring the news content of DN.se and of introducing the project to the readers in a blog on the $D N$ website, inviting them to join the 
discussion. She introduced the investigation in this way:

Swedish media have problems. And so does DN.se

The inequality is striking and nothing that we journalists do seems to change the situation. If we to some extent make any steps forward they are few and small; the development towards a more equal coverage is very slow. [...]

The readers of DN.se are not stupid. Obviously, you will notice that we are not able to live up to an equal reporting distribution on male and female subjects and sources. Now we want to do something about it. And the watchword during the project is transparency (Stiernstedt 2011).

The news content in DN.se is clearly gendered in terms of the distribution and status of the news sources, and of the representation of elites. In addition, women and men in the newsroom were not employed on equal terms. One of the prime factors in DN.se's news judgment often appears to be web site traffic. In a situation where the online newsroom must compete for resources with the print newsroom, the increase in web site traffic and the connected advertising revenues are the strongest arguments (cf. Allern 2012: 237). The interviews show a tension between market-based goals and journalist based targets. Without exception, the interviewed journalists agreed that gender equality is important, but when it comes to daily news work and decision-making, it was not a prioritized issue.

The reasons behind the exclusion of women's voices are many and complex. In the online environment, web metrics and the commodification of news could challenge features of journalism such as integrity, accountability, and meeting the needs of information for all people. One consequence of a competitive online journalism in combination with the lack of goal-oriented gender equality policies would be that gender parity in the newsroom is likely to be threatened and earlier accomplishments put at risk. In Jay Blumler's words, gender equality is a vulnerable value that deserves institutionalized protection (Blumler 1992). One such protection would be policy commitments and statements of support for gender equality at a managerial level. Also gender inequality is news production needs to be explicitly focused and addressed. However, the consistency of the symbolic annihilation of women in news media reminds us of the difficulties in changing policies and practices.

\section{References}

- AB Dagens Nyheter (2012). Årsredovisning för räkenskapsåret 2012 [Annual report for the financial year 2012]. Stockholm: AB Dagens Nyheter.

- AB Dagens Nyheter (2014). Arsredovisning för räkenskapsåret 2014 [Annual report for the financial year 2012]. Stockholm: AB Dagens Nyheter.

- Allern, S. (2002). Journalistic and commercial news values: News organizations as patrons of an institution and market actors. Nordicom Review 1-2/2002, 137-152.

- Allern, S. (2012). Journalistiken och kommersialiseringen [Journalism and commercialism]. In L. Nord, \& J. Strömbäck (Eds.) Medierna och demokratin [The media and democracy] (pp. 233-262). Lund: Studentlitteratur.
- Anderson, C. (2009). Web production, news judgment, and emerging categories of online newswork in metropolitan journalism. Retrieved from http:/ / online.journalism.utexas.edu/2009/paper s/Anderson09.pdf.

- Anderson, C.W. (2013). Rebuilding the news: Metropolitan journalism in the digital age. Philadelphia: Temple University Press.

- Bergström, A. \& Wadbring, I. (2010). Nya tidningsformer - konkurrenter eller komplement? [New Forms of Newspapers - competitors or complements?]. In S. Holmberg \& L. Weibull (Eds.) Nordiskt ljus [Nordic Light] (pp. 381-391). Göteborg: SOM-institutet, Göteborgs universitet.

- Blumler, J. G. (1992). Vulnerable values at stake. In J. G. Blumler (Ed.), Television and 
the public interest: Vulnerable values in west European broadcasting (pp. 22-42). London: Sage.

- Bruin, M.D. \& Ross, K. (Eds.) (2004). Gender and newsroom cultures: Identities at work. Cresskill, N.J.: Hampton.

- Burke, C.,\& Mazzarella, S. R. (2008). "A slightly new shade of lipstick": Gendered mediation in internet news stories. Women's Studies in Communication, 31, 395-418. doi:10.1080/07491409.2008.10162548.

- Buonanno, M. (2014). Gender and media studies: Progress and challenge in a vibrant research field. Anàlisi. Quaderns de Comunicació i Cultura, 50, 5-25. doi: http: / /dx.doi.org/10.7238/a.v0i50.2315

- Craft, S. \& Wanta, W. (2004). Women in the newsroom: Influences of female editors and reporters on the news agenda. Journalism \& Mass Communication Quarterly March 2004 vol. 81 no. 1, 124-138. doi: 10.1177/107769900408100109

- Dagens Nyheter (2011a). DN.se demografi, January 2011 [DN.se Demography, January 2011). Unpublished document. Stockholm: Dagens Nyheter.

- Dagens Nyheter (2011b). Värdegrund för DN.se [Values of DN.se]. Unpublished document, Dagens Nyheter 2011.

- Deuze, M. (2004). What is multimedia journalism?. Journalism Studies 5(2):139-152.

- Deuze, M. (2005). What is journalism?: Professional identity and ideology of journalists reconsidered', Journalism 6(4): 442-464.

- Djerf-Pierre, M. (2007). Journalisternas sociala bakgrund [The Social Background of Journalists]. In K. Asp (Ed.) Den svenska journalistkåren [Swedish Journalists] (pp. 1731). Göteborg: JMG.

- Djerf-Pierre, M. \& Löfgren-Nilsson, M. (2004). Gender-typing in the newsroom: The feminization of Swedish television news production 1958-2000. In M.D. Bruin \& K. Ross (Eds.) Gender and newsroom cultures: Identities at work (pp. 79-104). Cresskill, NJ: Hampton Press.

- Domingo, D. \& Paterson, C. A. (Eds.) (2011). Making online news. Volume 2,
Newsroom ethnographies in the second decade of internet journalism. New York: Peter Lang.

- Edström, M. (2006). TV-rummets eliter. Föreställningar om kön och makt i fakta och fiktion [The television elites: Images of gender and power in fact and fiction]. Göteborg: Göteborgs universitet.

- Edström, M. (2012). Is there a Nordic way? A Swedish perspective on achievements and problems with gender equality in the newsrooms. Medijske Studije/Media Studies 2 (3-4), 64-75. Retrieved from http: / / hrcak.srce.hr/index.php?show = clana k\&id_clanak_jezik=130755.

- Edström, M. Jacobson, M. \& Lindsten, S. (2010). Räkna med kvinnor 2010: Nationell rapport, Sverige. [Count women in 2010: National report, Sweden]. National report Global Media Monitoring Project 2010.

- Edström, M. \& Mølster, R. (Eds.) (2014). Making change: Nordic examples of working towards gender equality in the media. Göteborg: Nordicom.

- Eide, E. (1993). Journalisme og enkjønnet presentasjon [Journalism and Single-sex Presentation]. In U. Carlsson (Ed.), Nordisk forskning om kvinnor och medier [Nordic research on women and the media]. Göteborg: Nordicom.

- Facht, U. (Ed.) (2012). Medie-Sverige mini 2012 [Media Sweden mini 2012]. Göteborg: Nordicom-Sverige.

- Fagerjord, A. \& Storsul, T. (2007). Questioning convergence. In T. Storsul \& D. Stuedahl, (Eds.) Ambivalence towards convergence: Digitalization and media change. (pp. 1931). Göteborg: Nordicom.

- Fenton N. (2010). Drowning or waving? New media, journalism and democracy. In $\mathrm{N}$. Fenton, (ed.) New media, old news. London: Sage, pp.3-16.

- Galtung, J. \& Ruge, M.H. (1981). Structuring and selecting news. In Cohen, S. \& Young, J. (Eds.) The manufacture of news: social problems, deviance and the mass media, (pp. 5263).London: Constable. 
- Gallagher, M. (1995). An unfinished story: Gender patterns in media employment. Paris: Unesco Publ.

- Harcup, T. \& O’Neill, D. (2001). What is News? Galtung and Ruge revisited. In Journalism Studies vol 2, no2, 261-280, Doi: $10.1080 / 14616700118449$

- Hedman, U. (2006). "Har ni nåt webbigt?" En fallstudie av Göteborgs-Postens flerkanalspublicering. Redaktionell organisering och arbetsrutiner, nyhetsvärdering samt medielogik. ["Do you have something for the web?" A case study of multi-channel publishing at GöteborgsPosten: Editorial organization, working routines, news judgment, and media logic]. Göteborg: Göteborgs universitet.

- Hinderson, J. (2013). Webbens vägar: Om webbjournalistikens etablering och utveckling vid tre svenska regionala och lokala dagstidningar 1995-2013 [The ways of the web: About the establishment and development of web journalism at three Swedish local and regional newspapers]. Diss. Lund : Lunds universitet, 2013. Lund.

- Hvitfelt, H. (1985). På forrsta sidan [On the front page]. Stockholm: Styrelsen för psykologiskt försvar.

- Jones, J. \& Salter, L. (2012). Digital journalism. London: Sage.

- Löfgren Nilsson, M. (2004). Könsmärkning i SVT:s nyheter 1958-2003 [Gender typing of SVT's news 1958-2003]. Nordicom Information nr 4, 2004, 39-50.

- McChesney, R.W. (2013). Digital disconnect: How capitalism is turning the internet against democracy. New York: The New Press.

- McCracken, G. (1988). The long interview. Newbury Park, Calif.: Sage.

- Nikunen, K. (2013). Losing my profession: Age, experience and expertise in the changing newsrooms. Journalism, published online November 17, 2013, Doi: oi: $10.1177 / 1464884913508610$.

- Nordicom (2014). Mediestatistik [Media Statistics]. Retrieved from http: / / nordicom.gu.se/sv/mediefakta/medi estatistik (2 November 2015).
- O’Neill, D. \& Harcup, T. (2009). News values and selectivity. In $\mathrm{K}$. Wahl-Jorgensen \& T. Hanitzsch, (Eds.) The handbook of journalism studies (pp. 161-174). New York: Routledge.

- Presstödsnämnden (2012). Dagspressens ekonomi 2012 [The Economy of the Daily Press 2012]. Stockholm: Presstödsnämnden.

- Robinson, S. (2007). "Someone's gotta be in control here", Journalism Practice, 1:3, 305321, Doi: 10.1080/17512780701504856.

- Ross, K. \& Carter, C. (2011). Women and news: A long and winding road. Media, Culture \& Society 33(8), 1148-1165.

- Ross, K. (2011). Silent witness: News sources, the local press and the disappeared woman. In T. Krijnen, C. Alvares \& S.van Bauwel (Eds.) Gendered Transformations: Theory and Practices on Gender and Media (pp.9-23). Bristol: Intellect.

- Rättviseförmedlingen (2015). Rättvisaren [The fairness indicator]. Stockholm: Rättviseförmedlingen. Retrieved from http: / / rattviseformedlingen.se/wpcontent/uploads / 2015/11/Rttvisaren2015.pdf.

- Singer, J. B. (2004). Strange bedfellows? The diffusion of convergence in four news organizations'. Journalism Studies 5.1 (2004): 3-18.

- Statistics Sweden (2011). Arbetsmarknad [Labour market] Retrieved from http: / /www.scb.se/Pages/SSD/SSD_TreeV iew . aspx ?id=340478.

- Steiner, L. (2009). Gender in the newsroom. In K. Wahl-Jorgensen \& T. Hanitzsch, (Eds.) The handbook of journalism studies (pp. 116129). New York: Routledge.

- Steiner, L. (2012.) Failed Theories: Explaining Gender Difference. Journalism, Review of Communication, 12:3, 201-223. doi: 10.1080/15358593.2012.666559.

- Steiner, L. (2014). Feminist media theory. In R.S. Fortner \& M. Fackler (Eds.) The Handbook of media and mass communication theory (pp. 359-379. Chichester: Wiley.

- Stiernstedt, J. (2011, April 6). DN.se låter granska DN.se [DN.se allows examine 
DN.se] [Web log message]. Retrieved from http://blogg.dn.se/mangfald/2011/04/06/ dn-se-later-granska-dn-se/.

- Strömbäck, J. (2008). På nyhetsmediernas agendor: En studie av hot och risker i det svenska nyhetsurvalet i morgonpress, kvällspress och TV [On the agendas of news media: A study of threats and risks in the news selection of morning papers, tabloids and TV]. Sundsvall: Demokratiinstitutet.

- Sveriges Annonsörer (2011). KIA index, April 2011. Retrieved from http://www.kiaindex.se.

- TNS-Sifo (2010). Räckvidd- och upplageutveckling $2001-2010$ [Development of Reach and Circulation 2001 - 2010]. Retrieved from http://www.tns-

sifo.se/media/265516/tnssifo_rackvidd_och_up plageutveckling_2001-2010.pdf.

- Tuchman, G. (1979). Women's Depiction by the Mass Media. Signs, 4(3), 528-542. Retrieved from http://www.jstor.org/stable/3173399

- Tuchman, G. (1981). The Symbolic Annihilation of Women by the Mass Media. In Cohen, S. \& Young, J. (Eds.) The Manufacture of News: A Reader. Social Problems, Deviance and the Mass Media (pp. 169-185). London: Constable.
- Tuchman, G. (2003). Making news: A study in the construction of reality. New York: Free Press.

- Tuchman, G. (2007). New media, news media: The tension between pluralism and commodification. Nordicom Information 4/2007, 11-15.

- WACC (2010). Who makes the news? Global media monitoring project 2010. World Association for Christian Communication. Retrieved from http://whomakesthenews.org.

- Van Zoonen, L. (1998). One of the girls? Or the changing gender of journalism. In $\mathrm{C}$. Carter, G. Branston \& S. Allen (Eds.) News, gender and power (pp. 33-56). Routledge, London.

- Wiik, J. (2007). Granskningsidealet [The investigative ideal]. In K. Asp (Ed.), Den svenska journalistkåren [Swedish Journalists] (pp. 7986). Gothenburg: JMG.

- Yun, H. J. et al. (2007). Where is she? Coverage of women in online news magazines. Journalism Studies, 8, 930-947. doi: $10.1080 / 146167007015568$.

\section{Forma de Citación}

HULTEN, Gunilla: Newsroom Divides: Online News Production, Gender, and Organization at DN.se. Revista Communication Papers, No 7, páginas 22 a 34. Departamento de Filología y Comunicación de la Universidad de Girona. Recuperado el__de___ de 2___ de: http: / / www.communicationpapers.es

\footnotetext{
Notes

${ }^{i}$ No current official audited circulation figures are available for Dagens Nyheter.

${ }^{\text {ii }}$ For a definition of the concept of elite as used in this study, see Edström 2006.
} 